\title{
PARAMETARSKA, NEPARAMETARSKA I HIBRIDNA METODA IZRAČUNAVANJA VREDNOSTI PRI RIZIKU
}

\section{Dora Petronijević}

Univerzitet Singidunum, Beograd, Srbija

\begin{abstract}
Apstrakt:
Pitanje procene rizika kako pojedinačne aktive, tako i složenih portfolija, je jedno od najbitnijih i najizazovnijih pitanja u oblasti finansija. Ovaj rad se fokusira na VaR model (eng. Value at Risk), jedan od najznačajnijih i u praksi najčešće primenjivanih metoda za izračunavanje rizika. $V a R$ se može izračunati primenom parametarskih, neparametarskih i hibridnih metoda. U ovom radu će date metode biti primenjene na desetogodišnjim serijama prinosa: BELEX-a 15 (Indeks 15 hartija od vrednosti (HoV) kojima se trguje na Beogradskoj berzi) i četiri HoV: Soja protein, Imlek, Galenika Fitofarmacija i Energoprojekt, kojima se konitinuirano trguje na Beogradskoj berzi.

Cilj ovog rada je da se primenom datih metoda na analiziranim serijama ukaže na njihove pojedinačne prednosti i potencijalne nedostatke, kao i da ukaže u kojim situacijama je najprikladnije koristiti svaku od njih. Analizriaćemo adekvatnost primene parametarskog $V a R-a$, koji (u slučaju serija prinosa) pretpostavlja da podaci imaju lognormalnu distribuciju na date serije. Od neparametarskih metoda biće primenjene: istorijska metoda i bootstrap istorijska simulacija. U hibridnoj metodi obzervacije u uzorku dobijaju različit značaj, u zavisnosti od toga kada su se dogodile. U modelu parametar $\lambda$ utvrđuje brzinu opadanja značaja varijabli kroz vreme, a u radu će biti primenjene: $\lambda=0.95 \mathrm{i} \lambda=0.99$.
\end{abstract}

Ključne reči:

vrednost pri riziku - $V a R$, smanjivanje rizika, parametarska metoda,

neparametarska metoda, hibridna metoda.
Korespondencija:

Dora Petronijević

e-mail:

doracapa@yahoo.com
UVOD

Jedna od najbitnijih i najizazovnijih tema u oblasti finansija je adekvatna procena rizika. U praksi se za procenu rizika koristi više metoda, a jedna od najrasprostranjenijih je vrednost pri riziku (eng. Value at Risk - VaR).

VaR nam omogućava da sa određenom verovatnoćom (najčešće 99\% ili 95\%) utvrdimo nivo gubitka koji ne očekujemo da ćemo premašiti u određenom vremenskom periodu (Hull, 2009). Pošto se VaR fokusira na nivo gubitka, u praksi kažemo da računamo nivo gubitka koji možemo premašiti samo u $5 \%$ slučajeva, te se $V a R$ ne izražava u obiku: $V a R$ (95\%), već $\operatorname{VaR}(5 \%)$.

Modeli za izračunavanje $\mathrm{VaR}$-a se mogu podeliti na parametarske i neparametarske metode. Osnovna razlika između njih je to što je u primeni parametarskih modela neophodno prvo definisati distribuciju podataka, dok se neparametarske metode prilagođavaju samim podacima. Postoje i hibridne metode koje imaju elemente i neparametarske i parametarske metode. Ove metode će biti primenjene na indeks BELEX 15 i HoV četiri kompanije, uz analizu karakteristika, prednosti i mana svake od navedenih metoda. 
OSNOVNI PODACI O ANALIZRANIM SERIJAMA PODATAKA

U radu će biti primenjene različite metode za izračunavanje $V a R$-a na serijama prinosa indeksa BELEX $15^{1}$ i HoV četiri najlikvidnije kompanije na Beogradskoj berzi. Od odabranih kompanija Soja protein i Imlek pripadaju prehrambenoj industruji, Galenika Fitofarmacija (u nastavku: Galenika) pripada hemijskoj industriji, a Energoprojekt građevinskoj industriji.

S obzirom da će se sve analize u ovom radu fokusirati na rep distribucije $e^{2}$, veoma je bitno da posmatrani uzorak bude što veći. Iz tog razloga je za ovu analizu veoma povoljno što u poslednjih deset godina Beogradska berza poseduje dnevne podatke o trgovanju analiziranim HoV. Tako serije svih posmatranih hartija i indeksa imaju, svaka pojedinačno, više od 2500 obzervacija. Kada računamo $\operatorname{VaR}(5 \%)$ na ovako velikom uzorku, u rep distribucije ulazi preko 125 obzervacija, što omogućava kvalitetnu analizu rizičnosti serija.

Sve posmatrane serije će imati približnu veličinu uzorka, ali ne $\mathrm{i}$ istu. ${ }^{3}$ Kao kriterijum za početak posmatranog perioda uzet je trenutak kada je trgovanje $\mathrm{HoV}$ postalo kontinuirano. Ovaj datum se razlikuje kod različitih HoV. Razlog za uzimanje ovog datuma kao kriterijuma je taj što on garantuje postojanje prihvatljivog nivoa likvidnosti u trgovanju sa datom HoV. Razlog za neujednačavanje početnog datuma među serijama proizilazi iz činjenice da je za $V a R$ od izuzetnog značaja uključivanje što većeg broja obzervacija u analizu.

Istorijske cene analiziranih kompanija i indeksa će biti transformisane u seriju prinosa. Ova transformacija se vrši izračunavanjem geometrijskih prinosa. Geometrijski prinos je jednak logaritmovanom odnosu današnje i jučerašnje cene, u opštem obliku se izračunava formulom:

$$
\mathrm{R}_{\mathrm{t}}=\ln \left(\mathrm{P}_{\mathrm{t}} / \mathrm{P}_{\mathrm{t}-1}\right)
$$

gde:

$R_{t}$ predstavlja prinos, $P_{t}$ je cena u trenutku $\mathrm{t}$, a

$\mathrm{P}_{\mathrm{t}-1}$ je cena dan pre cene $\mathrm{P}_{\mathrm{t}}$ (Dowd, 2005).

Činjenica da ćemo u istraživnaju koristiti geometrijske prinose, nas upućuje na zaključak da, ako primenjujemo parametarsku metodu, analizirane serije (prinosi od četiri $\mathrm{HoV}$ i indeksa) moraju imati lognormalnu distribuciju. Odnosno, serije prinosa, koje su dobijene logaritmovanjem istorijskih

1 Struktura indeksne korpe BELEX 15: NIS, Aerodrom Nikola Tesla, Komercijalna banka, Energoprojekt holding, Galenika Fitofarmacija, Sojaprotein, AIK banka, Metalac, Imlek, Alfa plam, Messer Tehnogas, Jedinstvo, Goša montaža. Više o indeksu i načinu njegovog izračunavanja videti na sajtu Beogradske berze:

http://www.belex.rs/files/trgovanje/BELEX15_metodologija.pdf

2 U repu distribucije se nalaze najekstremniji događaji u seriji.

3 Tačni vremenski rasponi u kojima su serije analizirane su:

BELEX 15 (5.10.2005. - 4.03.2016.), Energoprojekt (11.01.2005. 4.03.2016.), Galenika (30.08.2005. - 4.03.2016.), Imlek (16.12.2005. cena $\mathrm{HoV}$, moraju imati normalnu distribuciju. Ukoliko se ovaj uslov zadovolji, rizičnost analiziranih serija možemo utvrditi primenom parametarske metode za izračunavanje $V a R-a$. U datoj situaciji bi bila korišćena formula (Dowd, 2005) za VaR prilagođena serijama sa lognormalnom distribucijom podataka:

$$
\operatorname{VaR}(\alpha \%)=\mathrm{P}_{\mathrm{t}-1}{ }^{*}\left(1-\exp \left(\mu_{\mathrm{R}}-\mathrm{z}_{\alpha}^{*} \sigma_{\mathrm{R}}\right)\right)
$$

gde:

$\boldsymbol{\mu}$ predstavlja srednju vrednost, $\boldsymbol{\sigma}$ standardnu devijaciju serije, a $z_{\alpha}$ predstavlja kritičnu vrednost $z$-statistika za normalnu distribuciju pri odabranom nivou verovatnoće. ${ }^{4}$

Ukoliko se ispostavi da ove serije nemaju normalnu distribuciju podataka, biće neophodno pronaći adekvatniju metodu za izračunavanje $V a R$-a.

Serije BELEX 15 i Imlek su najsimetričnije od posmatranih serija, te im je koeficijent asimetrije blizu nuli, što njihove distribucije čini bliskim normalnoj distribuciji. Za razliku od normalne distribucije, sve analizirane serije karakteriše veoma visok koeficijent spljoštenosti ${ }^{5}$. Koeficijent spljoštenosti u normalnoj distribuciji iznosi 3, dok kod posmatranih serija varira između: 8.11 i 17.41. Pored toga, vrednost Jarque-Bera test svih posmatranih serija je značajno viši od kritične vrednosti 5.99 ( $\chi^{2}$ raspodela sa dva stepena slobode za $\alpha=0.05$ ). Stoga možemo zaključiti da nijedna od analiziranih serija nema normalnu distribuciju.

Serije sa visokim koeficijentom spljoštenosti, u poređenju sa serijama koje imaju normalnu distribuciju, imaju veći procenat obzervacija koje su bliže srednjoj vrednosti, ali imaju i veći procenat vrednosti koje su značajno udaljene od srednje vrednosti. Stoga ovakve serije imaju deblje repove od normalne distribucije (više ekstremnih vrednosti). Drigim rečima, ovakve serije su rizičnije od serija sa normalnom distribucijom. S obzirom da je pretpostavka parametarskog $V a R$ modela da serija ima normalnu distribuciju, njegovom primenom na ovakvim serijama bismo automatski potcenili njihovu rizičnost (Jeremić \& Terzić, 2014). ${ }^{6}$

Iz tog razloga će u nastavku istraživanja biti korišćene neparametarske metode istraživanja koje se ne baziraju na unapred definisanoj distribuciji, već se prilagođavaju samim podacima. U ovom radu će za izračunavanje $V a R$-a, od neparametarskih metoda, biti korišćena metoda istorijske simulacije i metoda bootstrap istorijske simulacije.

4 S obzirom na to da se $\mathrm{VaR}$ fokusira na gubitke, on analizira samo jedan rep distribucije, te se pri utvrđivanju kritične vrednosti biraju vrednosti za distribuciju sa jednim repom.

5 Serije sa visokim koeficijentom spljoštenosti se nazivaju: leptokurtic

6 Jedan broj autora je razvio parametarski model za serije sa Studentovom $t$ raspodelom. $S$ obzirom na to da ova raspodela ima više koeficijente spljoštenosti od normalne distribucije, ova distribucija daje bolje rezultate kod ovakvih serija. Ipak, s obzirom da je jedna od pretpostavki Studentove t distribucije da koeficijent asimetrije treba biti jednak 0 (kao što je slučaj sa normalnom distribucijom), ova metoda nije prikladna za sve analizirane serije u ovom radu. 
Tabela 1. Testiranje normalnosti distribucija analiziranih serija

\begin{tabular}{lccccc}
\hline & BELEX 15 & Energoprojekt & Galenika & Imlek & Soja protein \\
\hline Analizirani period & $5.10 .2005 .-4.03 .2016$. & $11.01 .2005 .-4.03 .2016 .30 .08 .2005 .-4.03 .2016 .16 .12 .2005 .-4.03 .2016 .29 .03 .2005 .-4.03 .2016$. \\
\hline Veličina uzorka & 2623 & 2809 & 2644 & 2571 & 2750 \\
\hline Minimalna vrednost & $-10.86 \%$ & $-14.18 \%$ & $-22.33 \%$ & $-20.25 \%$ & $-22.31 \%$ \\
\hline Maksimalnavrednost & $12.16 \%$ & $18.16 \%$ & $18.25 \%$ & $18.22 \%$ & $13.12 \%$ \\
\hline Srednja vrednost & -0.0002 & 0.0002 & -0.0001 & 0.0005 & -0.0004 \\
\hline St. devijacija & 0.013 & 0.026 & 0.029 & 0.026 & 0.025 \\
\hline Koeficijent. asimetrije & 0.15 & 0.43 & -0.44 & 11 & -0.37 \\
\hline Koeficijent. spljoštenosti & 17.41 & 8.11 & 17.09 & 14.985 & 11.47 \\
\hline Jarque-Bera test & 22697.63 & 3140.48 & 21959.46 & 15393.53 & 8277.25 \\
\hline
\end{tabular}

Izvor: Podaci izračunati u Excel-u

\section{NEPARAMETARSKE METODE}

\section{Metoda istorijske simulacije}

Metoda istorijske simulacije je neparametarska metoda, u kojoj se $V a R$ izračunava na osnovu istorijskih prinosa određene aktive. Ova metoda implicitno pretpostavlja da će se trendovi iz prošlosti ponavljati i u budućnosti (Hull, 2009).

Pretpostavimo da želimo da izračunamo $\mathrm{VaR}(5 \%)$ za seriju prinosa sa uzorkom od 1000 podataka. Drugim rečima, želimo da nađemo nivo gubitka koji nećemo premašiti u više od $5 \%$ slučajeva.

Pri sprovođenju metode istorijske simulacije, prvi korak je ređanje podataka u seriji po visini prinosa, od najnižih ka najvišim. U sledećem koraku izdvajamo 5\% najviših gubitaka - u ovom primeru to je 50 obzervacija sa najvišim gubicima u seriji. VaR (5\%) je 51 obzervacija u uzorku. On se može posmatrati kao vrsta odsečka ili praga (eng. treshold) koji odvaja rep distribucije sa 5\% najrizičnijih obzervacija u distribuciji (Allen, Boudoukh i Saunders, 2004).

\section{Metoda bootstrap istorijske simulacije}

Bootstrap istorijaka simulacija je složenija verzija istorijske simulacije za izračunavanje $V a R$-a. Kao što joj ime kaže, ovom metodom se sprovodi veći broj simulacija na osnovu istorijskih podataka neke serije ili portfolia. Iz serije se izvlače manji uzorci podataka i za svaki od njih se računa vrednost $V a R$-a primenom metode istorijske simulacije. Nakon sprovođenja više simulacija, finalna vrednost $V a R$-a se dobija izvlačenjem proseka svih pojedinačnih vrednosti $V a R$-a dobijenih u različitim simulacijama. Empirijska istraživanja su pokazala da ova metoda daje tačnije procene rizika od metode istorijske simulacije (Dowd, 2005).

U tabeli 2 su predstavljene $\operatorname{VaR}(1 \%)$ i $V a R(5 \%)$ vrednosti analiziranih serija dobijene primenom ove dve neparametarske metode. Za svaku dobijenu vrednost $\mathrm{VaR}$-a je podebljan rezultat one metode koja je dala višu vrednost. S obzirom da serije imaju različiti broj obzervacija (između 2571 i 2750), u tabeli će uz rezultate istorijske simulacije biti istaknut i redni broj obzervacije koja u seriji predstavlja vrednost $V a R$-a. $V a R$ se može predstaviti i u novčanim vrednostima, što olakšava investitoru da stvori jasniju sliku o nivou gubitka koji potencijalno može ostvariti. Poslednja kolona u tabeli pokazuje kakve su procene pesimističnog modela (model koji procenjuje višu vrednost $V a R$-a) kada se posmatraju gubici u dinarima, i koliko će one biti veće od optimistične procene.

Obe metode su pokazale da od svih analiziranih serija BELEX 15 je imao najniže vrednosti VaR-a, što drugim rečima znači da je manje rizičan od drugih analiziranih serija. Ovaj rezultat ne iznenađuje, jer je BELEX 15 kao indeks diversifikovaniji i likvidniji od pojedinačnih HoV. Što se hartija od vrednosti kompanija tiče, kao najrizičnija se izdvojila Galenika.

Sve procentualne vrednosti $\mathrm{VaR}$-a date u tabeli se mogu i novčano predstaviti. Na primer, pretpostavimo da je investitor uložio u portfolio koji ima istu strukturu kao BELEX 15100.000 din. U jednom danu on ne bi trebalo da izgubi više od 1.869 din. u više od $5 \%$ slučajeva. Isto tako, po proračunu samo u $1 \%$ slučajeva bi mogao da izgubi više od 4.250 dinara. Drugim rečima, sa 95\% verovatnoće se očekuje da investitorov dnevni gubitak neće prevazići 1.869 din, odnosno sa $99 \%$ verovatnoće se očekuje da njegov gubitak neće biti viši od 4.250 dinara.

\section{Zaključci o analiziranim neparametarskim metodama}

Istraživanja su pokazala da rezultati bootstrap metode bolje procenjuju rizičnost aktive nego metoda istorijske simulacije. Ipak, prednost istorijske simulacije je što je jednostavnija za primenu. U prethodnoj analizi smo videli da rezultati dobijeni istorijskom simulacijom i bootstrap istorijskom simulacijom, iako donekle različiti, prate iste trendove (viši su kod rizičnijih aktiva, a niži kod manje rizičnih). Tako da obe metode daju veoma indikativne rezultate. 
Tabela 2. Izračunavanje $V a R$-a primenom istorijske simulacije i bootstrap istorijske simulacije

\begin{tabular}{|c|c|c|c|c|}
\hline & Istorijska simulacija & $\begin{array}{l}\text { Redni broj obzervacije } \\
\text { u istorijskoj metodi }\end{array}$ & $\begin{array}{l}\text { Bootstrap istorijska } \\
\text { simulacija }\end{array}$ & $\begin{array}{c}\text { Razlika u gubicima } \\
\text { između dva modela u } \\
\text { dinarima }\end{array}$ \\
\hline \multicolumn{5}{|l|}{ BELEX 15} \\
\hline VAR (1\%) & $-4.25 \%$ & 26 & $-3.30 \%$ & 950 \\
\hline VAR (5\%) & $-1.87 \%$ & 131 & $-1.89 \%$ & 20 \\
\hline \multicolumn{5}{|c|}{ ENERGOPROJEKT } \\
\hline VAR (1\%) & $-7.73 \%$ & 28 & $-6.98 \%$ & 750 \\
\hline VAR (5\%) & $-3.95 \%$ & 140 & $-4.12 \%$ & 170 \\
\hline \multicolumn{5}{|l|}{ IMLEK } \\
\hline VAR (1\%) & $-8.40 \%$ & 26 & $-9.07 \%$ & 670 \\
\hline VAR (5\%) & $-3.72 \%$ & 129 & $-3.77 \%$ & 50 \\
\hline \multicolumn{5}{|l|}{ GALENIKA } \\
\hline VAR (1\%) & $-9.59 \%$ & 26 & $-9.48 \%$ & 110 \\
\hline VAR (5\%) & $-4.30 \%$ & 132 & $-4.64 \%$ & 340 \\
\hline \multicolumn{5}{|c|}{ SOJA PROTEIN } \\
\hline VAR (1\%) & $-8.28 \%$ & 27 & $-7.70 \%$ & 580 \\
\hline VAR (5\%) & $-3.89 \%$ & 137 & $-3.98 \%$ & 90 \\
\hline
\end{tabular}

Izvor: Podaci izračunati u Excel-u

U odabiru metode, analitičar se može rukovoditi vremenom kojim raspolaže za pravljenje analize. Ukoliko ima više vremena, preporučljivije je da primeni bootstrap istorijsku simulaciju, jer će njome dobiti pouzdanije podatke, ali ako nema dovoljno vremena, vidimo da se inidkativni rezultati mogu dobiti primenom obične istorijske simulacije.

U narednom poglavlju će biti više reči o hibridnim metodama za izračunavanje $V a R$-a.

\section{Hibridna metoda}

Posmatrane metode za izračunavanje $V a R$-a daju jednaki značaj svim obzervacijama, nevezano za to kada su se dogodile. Hibridna metoda omogućava davanje različitog značaja (eng. weight) različitim podacima u zavisnosti od toga kada su se u prošlosti dogodili (Hull, 2009). Tako se najnovijim podacima daje najveći značaj, a što se dalje ide u prošlost, značaj podataka eksponencijalno opada.

Ova metoda predstavlja mešavinu parametarskih i neparametarskih metoda. Kao i neparametarske metode, ova metoda neće unapred postavljati pretpostavke o distribuciji podataka, već će se osloniti na istorijske podatake. Sa druge strane, ona daje različit značaj različitim obzervacijama u uzorku i u tom procesu primenjuje unapred utvrđenu formulu (te je zato delom parametarska).

Prvi korak u primeni ove metode je utvrđivanje nivoa značaja svake varijable u uzorku. To se čini primenom sledeće formule (Allen, Boudoukh i Saunders, 2004): $\left((1-\lambda) /\left(1-\lambda^{K}\right)\right)^{*} \lambda^{0},\left((1-\lambda) /\left(1-\lambda^{K}\right)\right)^{*} \lambda^{1}, \ldots,\left((1-\lambda) /\left(1-\lambda^{K}\right)\right)^{*} \lambda^{K-1}$

$\boldsymbol{K} \mathrm{u}$ formuli predstavlja veličinu uzorka, a $\boldsymbol{\lambda}$ (lamda) je parametar kojim se utvrđuje brzina opadanja značaja varijabli kroz vreme. Zbir svih nivoa značajnosti varijabli mora biti jednak 1, samim tim i ovaj parametar mora da se kreće između vrednosti 0 i 1 . U praksi se $\lambda$ obično daje vrednost između 0.9 i 1 . U ovom radu će biti korišćene vrednosti: $\lambda=0.95$ $\mathrm{i} \lambda=0.99$.

U drugom koraku ređamo varijable (prinosa) po veličini od najnižih ka najvišim. Nakon toga, pojedinačne značajnosti ovako poređanih varijabli sabiramo i na taj način dobijamo kumulativni značaj varijabli (eng. cumulative weight). Kumulativni značaj varijabli nam omogućuje da utvrdimo vrednost $V a R$-a (Boudoukh, Richardson i Whitelaw, 1998). Na primer, $\operatorname{VaR}(1 \%)$ je jednak nivou prinosa koji se dostiže kada kumulativna vrednost značaja pojedinačnih varijabli dostigne $1 \%$, $\operatorname{VaR}(5 \%)$ kada kumulativna vrednost dostigne 5\% itd.

$\mathrm{U}$ narednoj tabeli su date vrednosti $\mathrm{VaR}$-a analiziranih serija dobijene hibridnom metodom ( $s a \lambda=0.95 \mathrm{i} \lambda=0.99$ ).

Iz tabele se vidi da su rezultati $V a R$ - $a$ dobijeni ovom metodom niži za sve serije nego kada se primenjuje bootstrap metoda. Razlog proizilazi iz činjenice da većina serija nije imala ekstremne vrednosti u skorijoj budućnosti. Izuzetak je serija Soja protein u kojoj se po visini gubitka našla na 43 poziciji varijabla koja se dogodila pre 16 dana. Ova obzervacija je tako u modelu sa $\lambda=0.95$ imala nivo zanačajnosti od čak 
Tabela 3. $V a R$ vrednosti dobijene hibridnom metodom

\begin{tabular}{|c|c|c|c|c|c|}
\hline & $\begin{array}{l}\text { Vrednosti VaR } \\
\quad(\lambda=0.95)\end{array}$ & Broj obzervacija & $\begin{array}{l}\text { Vrednosti VaR } \\
\quad(\lambda=0.99)\end{array}$ & Broj obzervacija & $\begin{array}{l}\text { Bootstrap istori- } \\
\text { jska simulacija }\end{array}$ \\
\hline \multicolumn{6}{|l|}{ BELEX 15} \\
\hline VAR (1\%) & $-1.78 \%$ & 148 & $-1.78 \%$ & 148 & $-3.30 \%$ \\
\hline VAR (5\%) & $-1.09 \%$ & 316 & $-1.29 \%$ & 258 & $-1.89 \%$ \\
\hline \multicolumn{6}{|l|}{ ENERGOPROJEKT } \\
\hline VAR (1\%) & $-4.79 \%$ & 104 & $-4.95 \%$ & 101 & $-6.98 \%$ \\
\hline VAR (5\%) & $-3.50 \%$ & 177 & $-3.55 \%$ & 171 & $-4.12 \%$ \\
\hline \multicolumn{6}{|l|}{ IMLEK } \\
\hline VAR (1\%) & $-1.85 \%$ & 309 & $-3.63 \%$ & 146 & $-9.07 \%$ \\
\hline VAR (5\%) & $-1.30 \%$ & 404 & $-1.50 \%$ & 401 & $-3.77 \%$ \\
\hline \multicolumn{6}{|l|}{ GALENIKA } \\
\hline VAR (1\%) & $-5.40 \%$ & 83 & $-7.09 \%$ & 49 & $-9.48 \%$ \\
\hline VAR (5\%) & $-2.72 \%$ & 229 & $-2.73 \%$ & 229 & $-4.64 \%$ \\
\hline \multicolumn{6}{|l|}{ SOJA PROTEIN } \\
\hline $\operatorname{VAR}(1 \%)$ & $-6.49 \%$ & 43 & $-5.62 \%$ & 63 & $-7.70 \%$ \\
\hline VAR (5\%) & $-3.65 \%$ & 147 & $-3.62 \%$ & 150 & $-3.98 \%$ \\
\hline
\end{tabular}

Izvor: Podaci izračunati u Excel-u

$2.20 \%$. Sa druge strane, u modelu sa $\lambda=0.99$ je imala značajnost jednaku $0.85 \%$. Soja protein je zato jedina serija koja ima više vrednosti $V a R$-a u modelu sa $\lambda=0.95$, nego u modelu sa $\lambda=0.99 .^{7}$

Bitno je naglasiti da kada vršimo komparaciju $V a R$ vrednosti među kompanijama, odnosi rizičnosti ostaju isti, odnosno kompanije koje su imale više vrednosti $V a R$-a ih imaju i dalje, i obrnuto. Izuzetak je Imlek čije su VaR vrednosti dobijene hibridnom metodom dramatično niže od onih dobijenih bootstrap metodom. Ukoliko pogledamo kolonu Broj obzervacija, videćemo da je od svih posmatranih serija za Imlek bilo potrebno najviše obzervacija, da bi se dostigao kumulativni značaj od $1 \%$, odnosno $5 \%$. Naime najekstremnije vrednosti ove serije su se dogodile pre više od 6 godina, te je njihov nivo značajnosti u ovom modelu veoma nizak. To bi moglo dovesti do zaključka da je Imlek sigurnija HoV, nego što to ukazuje bootstrap istorijska simulacija.

Otvara se pitanje: kada je adekvatnije koristiti $V a R$ dobijen hibridnom metodom, a kada $V a R$ dobijen nekom od metoda koje svim varijablama daju isti značaj?

Autor ovog rada je mišljenja da hibridna metoda može biti dobar indikator rizika u kraćem vremenskom periodu. Veća je verovatnoća da će skoriji događaji imati uticaj na kretanje današnjih cena, nego davniji. Ipak, ukoliko želimo da saznamo kolike gubitke možemo ostvariti, ukoliko dođe do

7 U poređenju sa $\lambda=0.99$, model sa $\lambda=0.95$ daje veći značaj novijim podacima, ali i nivo značajnosti od obzervacije do obzervacije brže opada. Nakon prvih četrdesetak obzervacija, nivo značajnosti koji $\lambda=0.95$ daje obzervacijama je niži od nivoa koji daje $\lambda=0.99$ (npr. stota obzervacija u seriji ima značaj $\mathbf{0 . 0 0 0 3 1}$ u modelu sa $\lambda=0.95$, a 0.0037 u modelu sa $\lambda=0.99$ ). nekog ekstremnog, neočekivanog događaja, onda su nam za analizu svakako značajniji upravo događaji iz prošlosti, nevezano za to koliko davno su se dogodili. Na primer, hibridna metoda u našem modelu ne daje veliki značaj podacima iz 2008. i 2009. godine. Ipak, ukoliko bi se u budućnosti dogodila kriza slična onoj iz 2008. godine, analiza ovog perioda bi bila mnogo merodavnija za procenu potencijalnih gubitaka, nego analiza podataka koji su neposredno prethodili krizi.

\section{ZAKLJUČAK}

U ovom radu su prikazane karakteristike parametarske, neparametarskih i hibridne metode za izračunavanje $V a R$-a i prikazano je u kojim situacijama je najadekvatnije koristiti svaku od njih.

Utvrđeno je da analzirane serije nemaju normalnu distribuciju, te na njima nije prikladno primenjivati parametarsku metodu. U komparaciji neparametarskih metoda smo zaključili da bootstrap simulacija daje preciznije procene rizičnosti analizirane aktive, dok je istorijska metoda jednostavnija za izračunavanje. Iako manje precizna, istorijska metoda se pokazala kao metoda koja daje indikativne rezultate. Hibridna metoda je dobar indikator rizika u kraćem vremenskom periodu, jer daje veći značaj podacima iz bliže prošlosti.

Što se analiziranih serija tiče, rezultati svih primenjenih metoda su pokazali da je ulaganje u indeks BELEX 15 manje rizično od ulaganja u pojedinačne HoV. Pored toga, sve metode su na isti način rangirale analizirane $\mathrm{HoV}$ po rizičnosti (sa izuzetkom Imleka u hibridnoj metodi). 
Ovaj rad se fokusirao na $V a R$, no u praksi je preporučljivo pri analizi rizika pored $V a R$-a izračunati i očekivani gubitak (expected shortfall - ES) kojim se detaljnije analizira rep distribucije. Ovaj indikator se takođe može izračunavati primenom parametarskih i neparametarskih metoda. Još jedna interesantna metoda za analizu ekstremnijih događaja je teorija ekstremnih vrednosti, koja je originalno razvijena za predviđanje verovatnoće prirodnih nepogoda. Finalno, finansijska kriza 2008. godine je jasno pokazala da postojeći modeli za procenu rizika, iako korisni indikatori, svakako nisu dovoljni da se pojedinci i ekonomija u potpunosti zaštite od rizika. Iz tog razloga se pored datih metoda u analize sve češće uključuju dodatni kvalitativni indikatori, kao i elementi bihevioralne analize.

\section{LITERATURA}

Allen, L., Boudoukh, J., \& Saunders, A. (2004). Understanding Market, Credit and Operational Risk: The Value at Risk Approach. Oxford: Blackwell Publishing.

Beogradska berza. (2015). Hartije od vrednosti. Preuzeto 15.06.2016. sa $w w w . b e l e x . r s$

Bodie, Z., Kane, A., \& Marcus, A.J. (2009). Osnovi investicija. Beograd: Data Status.

Boudoukh, J., Richardson, M., \& Whitelaw, R.F. (1998). The Best of Both Worlds: A Hybrid Approach to Calculating Risk. doi:10.2139/ssrn.51420

Brooks, C. (2008). Introductory Econometrics for Finance. Cambridge: Cambridge University Press.
Reilly, F.K., \& Brown, K.C. (2009). Analysis of Investments and Management of Portfolios. Mason, OH: SouthWestern Cengage Learning.

Dowd, K. (2005). Measuring Market Risk. West Sussex, England: John Wiley \& Sons.

Hull, J. (2007). Risk Management and Financial Institutions. New Jersey: Pearson Prentice Hall.

Hull, J. (2009). Options, Futures and other Derivatives. New Jersey: Pearson Prentice Hall.

Jeremić, Z. \& Terzić, I. (2014). Empirical estimation and comparison of normal and Student-t linear VaR on the Belgrade Stock Exchange. Sinteza, 2014. doi: 10.15308/ sinteza-2014-298-302

Mills, T., \& Markellos, R.N. (2008). The Econometric Modelling of Financial Time Series. Cambridge: Cambridge University Press.

Mladenović, Z., \& Nojković, A. (2011). Analiza vremenskih serija: primeri iz srpske privrede. Beograd: Ekonomski fakultet.

Mladenović, Z., \& Petrović, P. (2010). Uvod u ekonometriju. Beograd: Ekonomski fakultet.

Schweser, K. (2014). Valuation and Risk Models. La Crosse, WI: Kaplan Schweser.

Schweser, K. (2015) Market Risk Measurement and Management. La Crosse, WI: Kaplan Schweser.

Tsay, R. (2010). Analysis of Financial Time Series. New Jersey: John Wiley \& Sons.

Wilmott, P. (2007). Frequently asked questions in quantitative finance. Chichester, UK: John Wiley \& Sons.

Wilmott, P. (2007). Paul Wilmott Introduces Quantitative finance. Chichester, UK: John Wiley \& Sons.

\section{PARAMETRIC, NON-PARAMETRIC AND HYBRID METHOD OF VAR CALCULATION APPLIED ON THE BELEX 15 CROP AND HOV FOUR COMPANIES FROM THE BELGRADE STOCK EXCHANGE}

\begin{abstract}
:
The question of risk assessment of the individual assets as well as the complex portfolios is one of the most important and challenging questions in the field of finance. This paper focuses on the $\mathrm{VaR}$ (Value at Risk) model which is one of the crucial methods and the most applied one in practice for risk calculation. In this paper, the mentioned methods will be applied on the ten-year yield series BELEX 15 (Index 15 of the securities traded on Belgrade Stock Exchange) and four securities: Soja protein, Imlek, Galenika Fitofarmacija and Energoprojekt which are continually traded on Belgrade Stock Exchange.

The goal of this paper is to indicate the individual advantages and potential disadvantages, by the application of the above mentioned methods on the analyzed series, as well as to explain the context for the possible application of those methods. We will analyze the application adequacy of the parametric VaR, which supposes that data have log-normal distribution (in the case of yield series). We will also apply historical method and Bootstrap historical simulation, out of the non-parametric methods. Hybrid method means that significance of the observations in the sample depends on the moment of happening. In the model, parameter $\lambda$ establishes the speed of declining of the variable importance throughout time; $\lambda=0.95$ and $\lambda=0.99$ will be applied in this paper.
\end{abstract}

\section{Keywords:}

VaR (Value at Risk),

risk reducement, parametric method, non-parametric method, hybrid method. 